\title{
Hubungan kemampuan koneksi matematika, rasa ingin tahu dan self- efficacy dengan kemampuan penalaran matematika
}

\author{
Hanifah Latifah Hadiat *, Karyati Karyati \\ Program Studi Pendidikan Matematika, Program Pascasarjana, Universitas Negeri Yogyakarta. \\ Jalan Colombo No. 1, Karangmalang, Yogyakarta 55281, Indonesia. \\ E-mail: hanifahhadiat29@gmail.com \\ * Corresponding Author
}

\section{ARTICLE INFO}

\section{Article history}

Received: 7 August 2019;

Revised: 30 Dec. 2019;

Accepted: 7 January 2020

\section{Keywords}

kemampuan koneksi matematika; rasa ingin tahu; self-efficacy; kemampuan penalaran matematika; mathematical connection ability; curiosity; athematical reasoning ability

\section{ABSTRACT}

Penelitian ini bertujuan untuk mendeskripsikan hubungan kemampuan koneksi matematika, rasa ingin tahu, dan self-efficacy dengan kemampuan penalaran matematis siswa SMA. Penelitian ini merupakan penelitian kuantitatif dengan jenis penelitian ex post facto. Populasi penelitian mencakup seluruh siswa kelas $\mathrm{X}$ di Kabupaten Brebes. Sampel adalah 362 siswa yang berasal dari enam sekolah di Kabupaten Brebes ditentukan dengan stratified propotional random sampling technique. Pengumpulan data dilakukan menggunakan tes dan angket dengan skala likert. Teknik analisis data yang digunakan adalah analisis linier ganda dan analisis korelasi parsial. Hasil penelitian menunjukkan bahwa kemampuan koneksi matematis, rasa ingin tahu, dan self-efficacy secara bersama-sama berhubungan dengan kemampuan penalaran matematika siswa SMA, dimana kontribusi yang diberikan sebesar 46,3\%, serta persamaan regresi yang diperoleh yaitu $Y=0,97+0,422 X_{1}+0,059 X_{2}+0,041 X_{3}$. Hubungan antara kemampuan koneksi matematis $\left(\mathrm{X}_{1}\right)$ dengan kemampuan penalaran $(\mathrm{Y})$ dengan kontribusi sebesar $23,27 \%$. Hubungan antara rasa ingin tahu $\left(\mathrm{X}_{2}\right)$ dengan kemampuan penalaran dengan kontribusi sebesar 3,59\%. Hubungan antara self-efficacy $\left(\mathrm{X}_{3}\right)$ dengan kemampuan penalaran dengan kontribusi sebesar $1,81 \%$.

This study aimed to describe the relationship between mathematical connection ability, curiosity, and self-efficacy and the mathematical reasoning ability of senior high school students. This study was a quantitative ex post facto study. The population comprised all tenth-grade students of senior high school in Brebes District, Indonesia. The sample was 362 students from six schools that were established using the stratified proportional random sampling technique. The data were collected through a test and Likert-scale questionnaires. The data were analyzed using multiple regression and partial correlation analysis. The results showed that mathematical connection ability, curiosity, and selfefficacy, as an aggregate correlated with mathematical reasoning ability, with a contribution of $46,3 \%$ obtained by the regression model $Y=0.97+0.422 X_{1}$ $+0.059 X_{2}+0.041 X_{3}$. The relationship between mathematical connection and mathematical reasoning ability with the contribution of $23.27 \%$. The relationship between curiosity and mathematical reasoning ability with the contribution of $3.59 \%$. The relationship between self-efficacy and mathematical reasoning ability with the contribution of $1.81 \%$.

This is an open-access article under the CC-BY-SA license.

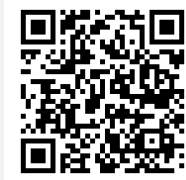

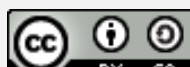

How to Cite: Hadiat, H., \& Karyati, K. (2019). Hubungan kemampuan koneksi matematika, rasa ingin tahu dan self-efficacy dengan kemampuan penalaran matematika. Jurnal Riset Pendidikan Matematika, 6(2), 200-210. doi:https://doi.org/10.21831/jrpm.v6i2.26552 


\section{PENDAHULUAN}

Kemampuan penalaran matematis adalah salah satu kemampuan yang penting untuk mempelajari matematika. Hal itulah yang menyebabkan Indonesia menjadikan kemampuan penalaran matematis sebagai salah satu kompetensi penting yang harus dikuasai oleh siswa. Peraturan Menteri Pendidikan dan Kebudayaan Republik Indonesia Nomor 21 Tahun 2016 tentang Standar Isi Pendidikan Dasar dan Menengah menjelaskan bahwa keterampilan siswa salah satunya dikembangkan lewat aktivitas menalar (Peraturan Menteri Pendidikan dan Kebudayaan Republik Indonesia Nomor 21 Tahun 2016 tentang Standar Isi Pendidikan Dasar dan Menengah, 2016). Pentingnya kemampuan penalaran matematika bagi siswa diperkuat oleh National Council Teacher of Mathematics (NCTM) yang menyatakan bahwa matematika sekolah memiliki standar-standar yang harus dimiliki oleh siswa yaitu standar isi dan standar proses. Standar proses meliputi kemampuan pemecahan masalah, kemampuan penalaran dan pembuktian, kemampuan koneksi matematika, dan kemampuan komunikasi matematika (National Council of Teachers of Mathematics, 2000, p. 21). Selain itu, kelancaran prosedural siswa dalam menyelesaikan masalah matematika dan pemahaman konseptual dapat dikembangkan melalui penalaran (National Council of Teachers of Mathematics, 2000, p. 30).

Penalaran merupakan salah satu kemampuan dasar yang diperlukan oleh siswa dalam belajar matematika karena hampir di semua tingkat pemahaman matematika membutuhkan penalaran (Sidenvall et al., 2015). Hal ini sejalan dengan pendapat yang menyatakan bahwa proses penalaran mendukung pemahaman dalam belajar matematika (Ball et al., 2008; Ontario Ministry of Education, 2005). Kemampuan penalaran matematika membantu siswa dalam memunculkan rasa untuk memahami ide-ide dan konsep yang ada pada prosedur, yang artinya ketika siswa melakukan proses penalaran matematis, siswa tidak hanya menghafal rumus dan prosedur pengerjaan, akan tetapi siswa juga mencoba memahami ide-ide dan konsep yang digunakannya (Bieda et al., 2014, p. 9). Dengan demikian dapat disimpulkan bahwa penalaran merupakan hal yang penting.

Pada kenyataannya, meskipun kemampuan penalaran itu penting, siswa di Indonesia masih memiliki kemampuan penalaran yang rendah. Hal ini ditunjukkan dari hasil penelitian Programme for International Student Assessment (PISA) yang berfokus pada penelitian tentang kemampuan literasi matematis. Literasi matematis sebagai suatu kapasitas individu dalam memformulasikan, menggunakan dan menafsirkan matematika dalam berbagai konteks, termasuk di dalamnya penalaran secara matematis (Organisation for Economic Co-operation and Development, 2013). PISA membagi tingkatan keahlian dalam matematika ke dalam enam level. Level diurutkan berdasarkan skor yang diperoleh suatu negara pada uji yang dilaksanakan oleh PISA. Siswa dikatakan telah memiliki kemampuan menalar jika skornya berada pada level tiga hingga enam. Hasil PISA menunjukkan bahwa dari tahun 2003, 2006, 2009, 2012, dan 2015, Indonesia meraih skor berturut-turut 360, 391, 371, 375, dan 386 yang menunjukkan bahwa Indonesia berada pada level satu (Organisation for Economic Co-Operation and Development, 2004, 2009, 2010, 2014, 2016). Hasil tersebut jelas menunjukkan bahwa siswa Indonesia bisa dikatakan belum memiliki kemampuan penalaran yang baik.

Para ahli memiliki definisi yang hampir sama satu sama lain mengenai kemampuan penalaran matematis. Russell menyatakan bahwa kemampuan penalaran matematis secara esensial adalah tentang pengembangan, pemberian alasan, dan penggunaan generalisasi matematika (Brodie, 2010, p. 9). Bieda et al. (2014, p. 9) menyatakan bahwa kemampuan penalaran matematis mengarah pada kemampuan untuk menganalisis masalah matematika dan membuat argumen yang logis dari permasalahan tersebut. Penalaran matematis melibatkan membuat, menyelidiki dan mengevaluasi dugaan atau konjektur, dan mengembangkan argumen matematika untuk meyakinkan diri sendiri dan orang lain bahwa dugaan itu benar (Goos et al., 2007, p. 35). Siswa yang memiliki kemampuan yang baik akan mencoba untuk meyakinkan dirinya dalam membuat konjektur dari rangkaian konjektur-konjektur yang ada dengan menyelidiki dan mengevaluasi apakah konjektur yang ia buat merupakan sebuah konjektur yang benar. Bernalar matematika itu meliputi mengamati pola, berpikir tentang pola, dan memberikan alasan mengapa pola itu harus benar pada lebih dari satu contoh (Reys et al., 2014).

Kemampuan yang tidak kalah penting dari kemampuan penalaran adalah kemampuan koneksi matematis. Matematika bukanlah materi atau topik yang terpisah-pisah, akan tetapi saling berkaitan antara yang satu dengan yang lain. Ketika siswa dapat melihat koneksi antara konten matematika yang berbeda, maka siswa telah mengembangkan nilai matematika sebagai suatu satu kesatuan yang saling terintegrasi (National Council of Teachers of Mathematics, 2000, p. 354). Kemampuan koneksi mate- 
matis adalah kemampuan mengenali dan menggunakan ide-ide matematika, mengetahui bagaimana ideide matematika terkoneksi dan terbangun antar satu sama lain secara keseluruhan, mengenali dan menerapkan matematika di luar konteks matematika (National Council of Teachers of Mathematics, 2000, p. 64). Ministry of Education (2004) menyatakan bahwa koneksi merujuk pada kemampuan untuk melihat dan membuat hubungan antara ide matematika, antara matematika dengan pelajaran lain, dan antara matematika dan kehidupan sehari-hari.

García-García dan Dolores-Flores (2018, p. 230) menyatakan bahwa kemampuan koneksi matematis merupakan suatu proses kognitif yang mana seseorang menghubungkan dua atau lebih ide-ide, konsep, definisi, prosedur, representasi dan maknanya satu sama lain, dengan disiplin ilmu lain atau dengan kehidupan nyata. Ini artinya kemampuan koneksi matematika tidak hanya mencangkup koneksi antara topik atau materi matematika saja, akan tetapi mencangkup antara matematika dengan bidang ilmu lainnya dan dengan kehidupan sehari-hari. Di samping itu, kemampuan penalaran matematis berhubungan sangat erat dengan kemampuan koneksi matematika. Hal ini sesuai dengan pernyataan NCTM yang menyatakan bahwa penalaran siswa tentang matematika adalah mengoneksikan apa yang mereka pelajari dengan pengetahuan yang sudah ada, dan membuat maksud dari sebuah formula menjadi masuk akal (National Council of Teachers of Mathematics, 2009, p. 6).

Kemampuan penalaran matematika siswa juga berhubungan erat dengan kemampuan afektif yang dimiliki. Di antara kemampuan afektif yang memiliki pengaruh dan berhubungan erat dengan kemampuan penalaran matematika siswa adalah rasa ingin tahu siswa terhadap matematika. Rasa ingin tahu memiliki hubungan simbiotik dengan penalaran. Rasa ingin tahu adalah titik awal yang penting untuk membujuk anak untuk terlibat dalam matematika melebihi prosedur yang dipelajari yang menyebabkan mereka melibatkan penalarannya (Witt \& Hansen, 2014). Rasa ingin tahu adalah keinginan untuk belajar dan mempelajari sesuatu agar mendapat informasi ataupun pengetahuan baru (Renner, 2006). Rasa ingin tahu juga mendorong siswa melakukan kegiatan eksplorasi (Litman \& Spielberger, 2003, p. 75). Selain dengan aktivitas eksplorasi, rasa ingin tahu siswa terhadap matematika juga dapat ditunjukkan dengan aktivitas bertanya siswa terhadap hal yang berkaitan dengan matematika. Sehingga dapat disimpulkan bahwa rasa ingin tahu adalah keinginan untuk memahami dan mempelajari matematika lebih mendalam guna mendapatkan pengetahuan baru yang ditunjukkan melalui kegiatan bereksplorasi dan keaktifan dalam bertanya.

Kemampuan afektif lainnya yang memiliki pengaruh terhadap kemampuan penalaran matematika siswa adalah self-efficacy karena merupakan salah satu faktor yang penting dalam keberhasilan belajar. Self-efficacy berkaitan erat tentang keyakinan seseorang akan kemampuan yang dimiliki. Self-efficacy adalah penilaian seseorang tentang kemampuan diri untuk menjalankan perilaku tertentu atau mencapai tujuan tertentu (Ormord, 2009). Bhowmick et al. (2017, p. 106) menyatakan bahwa self-efficacy sebagai salah satu bentuk kepercayaan diri terhadap kemampuan seseorang untuk melakukan atau menyelesaikan tugas matematika.

Self-efficacy dapat mempengaruhi aktivitas siswa, dimana apabila siswa memiliki self-efficacy yang rendah dalam belajar mereka akan menghindari tugas. Namun mereka yang menilai dirinya memiliki self-efficacy yang cukup, lebih bersemangat untuk berpartisipasi (McCoach et al., 2013, p. 11). Selfefficacy juga dapat didefinisikan sebagai persepsi dan kepercayaan terhadap dirinya bahwa ia dapat menyelesaikan tugas yang diberikan (McCoach et al., 2013; Sengul, 2011). Self-efficacy juga dapat mempengaruhi banyaknya usaha yang dilakukan siswa dan keuletan dalam pembelajaran. Siswa yang memiliki self-efficacy dalam belajar umumnya memberikan usaha yang lebih besar dan bertahan lama dibanding siswa yang meragukan kapabilitas mereka terutama ketika mereka menemui kesulitan (Schunk, 2012).

Berdasarkan pemaparan yang telah dikemukakan, dapat disimpulkan bahwa kemampuan koneksi matematis, rasa ingin tahu, self-efficacy dan kemampuan penalaran matematis adalah hal yang penting bagi peningkatan pemahaman siswa. Selain itu, berdasarkan teori yang dipaparkan terdapat hubungan di antara kemampuan koneksi matematika, rasa ingin tahu dan self-efficacy dengan kemampuan penalaran matematika. Oleh karena itu penting untuk mengetahui dan mendeskripsikan hubungan antar kemampuan koneksi matematis, rasa ingin tahu, self-efficacy dan kemampuan penalaran matematis yang dimiliki oleh siswa, sehingga dapat dijadikan sebagai referensi bagi guru untuk dapat memperbaiki kemampuan matematika yang dimiliki oleh siswa. 


\section{METODE}

Penelitian ini adalah penelitian kuantitatif dengan jenis penelitian ex post facto. Penelitian ini disebut penelitian ex post facto karena penelitian ini meneliti variabel yang sudah ada. Penelitian ini dilaksanakan di SMA yang berada di wilayah Kabupaten Brebes. Populasi pada penelitian ini adalah seluruh siswa SMA kelas X di Kabupaten Brebes yang terdiri dari 17 SMA negeri dan 15 SMA swasta. Sampel dalam penelitian ini berjumlah 362 siswa. Sampel berasal dari enam sekolah yang ditentukan dengan stratified propotional random sampling. Sekolah digolongkan berdasarkan akreditasi sekolah, kemudian dipilih enam sekolah yang terdiri dari tiga sekolah dengan akreditasi A, dua sekolah dengan akreditasi B, dan satu sekolah dengan akreditasi C.

Dalam penelitian ini terdapat tiga variabel bebas dan satu variabel terikat. Variabel bebas terdiri dari kemampuan koneksi matematis $\left(\mathrm{X}_{1}\right)$, rasa ingin tahu $\left(\mathrm{X}_{2}\right)$, dan self-efficacy $\left(\mathrm{X}_{3}\right)$. Variabel terikat dalam penelitian ini adalah kemampuan penalaran matematis (Y). Instrumen dalam penelitian ini adalah tes dan non tes. Instrumen tes berbentuk soal uraian digunakan untuk mengukur kemampuan koneksi matematis dan kemampuan penalaran matematis. Soal tes kemampuan koneksi matematis dan kemampu-an penalaran terdiri dari tiga soal uraian berisi satu soal terkait materi geometri, satu soal terkait materi aljabar dan satu soal yang terkait dengan materi statistika yang kemudian ketiga soal tersebut dikerjakan oleh siswa dalam waktu 60 menit. Setiap soal uraian pada tes kemampuan koneksi matematis mengandung indikator kemampuan matematis yaitu menggunakan konsep antar matematika untuk menyelesaikan soal matematika, menggunakan konsep matematika dan disiplin ilmu lain untuk menyelesaikan soal matematika, dan menggunakan konsep matematika untuk menyelesaikan masalah kehidup-an sehari-hari yang terkait dengan matematika. Setiap soal uraian pada tes kemampuan penalaran mengandung indikator kemampuan penalaran yaitu menyusun argumen secara logis, mengevaluasi konjektur, menggunakan generalisasi, menarik kesimpulan.

Instrumen non tes berbentuk angket dengan skala Likert dengan lima alternatif jawaban yaitu selalu, sering, kadang-kadang, jarang, dan tidak pernah, digunakan untuk mengukur rasa ingin tahu dan self-efficacy siswa. Angket rasa ingin tahu berisi tiga puluh butir pertanyaan tertutup positif dan negatif yang mengandung indikator rasa ingin tahu yaitu keinginan untuk mempelajari matematika, melakukan kegiatan eksplorasi dan aktif bertanya mengenai matematika. Angket self-efficacy tahu berisi tiga puluh butir pertanyaan tertutup yang mengandung indikator self-efficacy yaitu keyakinan akan kemampuan diri, keyakinan dapat menyelesaikan tugas-tugas matematika, dan keyakinan dapat mencapai tujuan.

Validitas tes dan angket dibuktikan dengan meminta pendapat para ahli yang terdiri dari dua dosen Program Studi Pendidikan Matematika, Program Pascasarjana Universitas Negeri Yogyakarta. Prosedur dalam menvalidasi instrumen adalah dengan cara memberikan instrumen untuk divalidasi dengan standar penilaian mengacu pada lembar validasi. Hasil dari validasi para ahli menyatakan bahwa instrumen layak digunakan dengan syarat revisi sesuai dengan saran yang diberikan ahli.

Reliabilitas instrumen diestimasi dengan menggunakan rumus Alpha Cronbach's. Berdasarkan hasil perhitungan diperoleh koefisien reliabilitas instrumen kemampuan koneksi matematis adalah 0,66 dengan estimasi Standard Error Measurement (SEM) yaitu 1,76. Koefisien reliabilitas instrumen rasa ingin tahu adalah 0,84 dengan estimasi SEM yaitu 2,17. Koefisien reliabilitas instrumen self-efficacy adalah 0,88 dengan estimasi SEM yaitu 1,78. Koefisien reliabilitas instrumen kemampuan penalaran matematis adalah 0,67 dengan estimasi SEM yaitu 1,5. Karena pada masing-masing instrumen memiliki nilai koefisien reliabilitas di atas 0,60 maka dapat dikategorikan tinggi, sehingga instrumen ini baik dan layak untuk digunakan dalam penelitian.

Data hasil penelitian ini dianalisis menggunakan statistik deskriptif dan inferensial. Data setiap variabel dideskripsikan dengan kategorisasi yang terdiri dari lima kategori yaitu sangat tinggi, tinggi, sedang, rendah, sangat rendah dengan mengacu pada kriteria yang dikemukakan oleh Azwar (2004), seperti disajikan pada Tabel 1 .

Selanjutnya dilakukan uji statistik inferensial untuk membuktikan hipotesis penelitian. Namun sebelum dilakukan uji hipotesis, terlebih dahulu dilakukan uji asumsi. Dalam penelitian ini uji asumsi analisis meliputi uji normalitas, uji heteroskedastisitas, uji multi kolinieritas, dan uji autokorelasi. Adapun pengujian hipotesis menggunakan analisis regresi linier ganda. Sedangkan untuk mengetahui korelasi masing-masing variabel bebas dengan variabel terikat digunakan analisis korelasi parsial. Sebagai kriteria penerimaan dan penolakan hipotesis digunakan tingkat signifikansi $5 \%(0,05)$. 
Jurnal Riset Pendidikan Matematika, 6 (2), 2019 - 204

Hanifah Latifah Hadiat, Karyati Karyati

Tabel 1. Kategorisasi Data Penelitian

\begin{tabular}{ll}
\hline Interval & Kriteria \\
\hline$X>M i+1,5 S i$ & Sangat tinggi \\
$M i+0,5 S i<X \leq M i+1,5 S i$ & Tinggi \\
$M i-0,5 S i<X \leq M i+0,5 S i$ & Sedang \\
$M i-1,5 S i<X \leq M i-0,5 S i$ & Rendah \\
$X \leq M i-1,5 S i$ & Sangat Rendah \\
\hline
\end{tabular}

Keterangan: $M_{l}=$ rata-rata ideal, $S_{i}=$ simpangan baku ideal, dan $X=$ skor empiris.

\section{HASIL DAN PEMBAHASAN}

Data yang diperoleh dari hasil penelitian dideskripsikan berdasarkan masing-masing variabel sesuai dengan kategori yang telah ditentukan. Hasil perhitungan melalui statistik deskriptif untuk kemampuan koneksi matematika, rasa ingin tahu, self-efficacy, dan kemampuan penalaran matematika menunjukkan sebagian besar siswa memiliki kecenderungan kemampuan yang sedang. Kemampuan koneksi siswa ditunjukkan pada Tabel 2.

Tabel 2. Distribusi Kemampuan Koneksi Matematika

\begin{tabular}{lll}
\hline Kategori & $n$ & $\%$ \\
\hline Sangat Tinggi & 48 & 13,26 \\
Tinggi & 121 & 33,43 \\
Sedang & 142 & 39,23 \\
Rendah & 49 & 13,54 \\
Sangat Rendah & 2 & 0,55 \\
\hline Total & 362 & 100 \\
\hline
\end{tabular}

Pada Tabel 2 dapat dilihat bahwa sebanyak 142 siswa atau 39,23\% dari 362 siswa terpilih memiliki kemampuan koneksi dalam kategori sedang. Kemampuan koneksi matematika sangat tinggi dicapai oleh 48 siswa atau 13,26\% dan kategori tinggi dicapai oleh 121 siswa atau 33,43\%. Responden yang mencapai kategori rendah cukup banyak yaitu 49 siswa atau 13,54\% sedangkan pada kategori sangat rendah hanya 2 siswa atau $0,55 \%$.

Tabel 3. Distribusi Rasa Ingin Tahu

\begin{tabular}{lll}
\hline Kategori & $n$ & $\%$ \\
\hline Sangat Tinggi & 8 & 2,21 \\
Tinggi & 53 & 14,64 \\
Sedang & 217 & 59,94 \\
Rendah & 80 & 22,10 \\
Sangat Rendah & 4 & 1,10 \\
\hline Total & 362 & 100 \\
\hline
\end{tabular}

Selanjutnya hasil kategori rasa ingin tahu siswa ditunjukkan oleh Tabel 3. Pada Tabel 3 dapat dilihat bahwa secara umum siswa memiliki rasa ingin tahu kategori sedang yaitu sebanyak 217 siswa atau 59,94\% dari jumlah keseluruhan responden berada pada kategori sedang. Rasa ingin tahu siswa yang berada pada kategori sangat tinggi dicapai oleh 8 siswa atau 2,21\% dan rasa ingin tahu kategori tinggi dicapai 53 siswa atau 14,64\%. Siswa yang mencapai rasa ingin tahu pada kategori rendah cukup banyak yaitu 80 siswa atau 22,10\% sedangkan pada kategori sangat rendah hanya 4 siswa siswa atau $1,10 \%$.

Tabel 4. Distribusi Self-Efficacy

\begin{tabular}{lll}
\hline Kategori & $n$ & $\%$ \\
\hline Sangat Tinggi & 19 & 2,21 \\
Tinggi & 103 & 14,64 \\
Sedang & 200 & 59,94 \\
Rendah & 38 & 22,10 \\
Sangat Rendah & 2 & 1,10 \\
\hline Total & 362 & 100 \\
\hline
\end{tabular}


Selanjutnya self-efficacy siswa ditunjukkan oleh Tabel 4. Pada Tabel 4 dapat dilihat bahwa secara umum siswa memiliki self-efficacy kategori sedang yaitu 200 siswa atau 55,25\% dari 362 siswa. Selfefficacy sangat tinggi dicapai oleh 19 siswa atau 5,25\% dan kategori tinggi dicapai 103 siswa atau $28,45 \%$ siswa yang mencapai kategori rendah cukup banyak yaitu 38 orang atau 10,50\% sedangkan pada kategori sangat rendah hanya didapat oleh 2 siswa atau $0,55 \%$ dari keseluruhan siswa.

Tabel 5. Distribusi Kemampuan Penalaran Matematika

\begin{tabular}{lll}
\hline Kategori & $n$ & $\%$ \\
\hline Sangat Tinggi & 35 & 9,67 \\
Tinggi & 142 & 39,23 \\
Sedang & 154 & 42,54 \\
Rendah & 31 & 8,56 \\
Sangat Rendah & 0 & 0 \\
\hline Total & 362 & 100 \\
\hline
\end{tabular}

Kemampuan penalaran matematika responden ditunjukkan oleh Tabel 5. Pada Tabel 5 dapat dilihat bahwa secara umum siswa memiliki kemampuan penalaran matematika kategori sedang yaitu 154 siswa atau 42,54\% dari 362 siswa. Kemampuan penalaran matematika sangat tinggi dicapai oleh 35 siswa atau 9,67\% dari 362 siswa. Kategori tinggi dicapai 142 siswa atau 39,23\% siswa yang mencapai kategori rendah yaitu 31 siswa atau $22,10 \%$.

\section{Uji Hipotesis Pertama}

Hipotesis pertama yang akan diuji yaitu apakah ada hubungan antara kemampuan koneksi matematis, rasa ingin tahu dan self-efficacy secara bersama-sama (simultan) dengan kemampuan penalaran matematis. Koefisien korelasi $(R)$ digunakan untuk mengetahui keeratan hubungan antara kemampuan koneksi matematika, rasa ingin tahu, dan self-efficacy dengan kemampuan penalaran matematika. Koefisien korelasi $(R)$ untuk kemampuan koneksi matematika, rasa ingin tahu dan selfefficacy secara simultan dengan kemampuan penalaran matematika adalah 0,684. Berarti terdapat tingkat hubungan yang kuat antara kemampuan koneksi matematis, rasa ingin tahu dan self-efficacy secara simultan dengan kemampuan penalaran matematis. Hubungan antara semua variabel bebas secara simultan dengan variabel terikat berdasarkan juga signifikan $(F=104,797 ; p=0.00)$ Dengan demikian hipotesis pertama terbukti, bahwa ada hubungan yang signifikan antara kemampuan koneksi matematika, rasa ingin tahu, dan self-efficacy secara simultan dengan kemampuan penalaran matematika siswa. Nilai koefisien determinasi $\left(R^{2}\right)$ yang disesuaikan diperoleh sebesar $43,6 \%$, artinya sebesar 46,3\% kemampuan penalaran siswa kelas X SMA di Kabupaten Brebes dapat dijelaskan menggunakan kemampuan koneksi matematis, rasa ingin tahu, dan self-efficacy. Sisanya sebesar 53,7\% merupakan sumbangan variabel lain yang dapat berpengaruh terhadap kemampuan penalaran matematis siswa yang belum diteliti.

Hasil analisis lanjut (lihat Tabel 6) terhadap hubungan tersebut memperlihatkan bahwa setiap peningkatan atau penurunan satu unit satuan variabel kemampuan koneksi matematis $\left(\mathrm{X}_{1}\right)$ akan diikuti oleh peningkatan atau penurunan sebesar 0,422 pada variabel kemampuan penalaran matematis (Y), setiap peningkatan atau penurunan satu unit satuan variabel rasa ingin tahu $\left(\mathrm{X}_{2}\right)$ akan diikuti oleh peningkatan atau penurunan sebesar 0,059 pada variabel kemampuan penalaran matematika (Y), setiap peningkatan atau penurunan satu unit satuan variabel self-efficacy $\left(\mathrm{X}_{3}\right)$ akan diikuti oleh peningkatan atau penurunan sebesar 0,041 pada variabel kemampuan penalaran matematika (Y). Sehingga dapat disimpulkan bahwa semakin tinggi kemampuan koneksi matematika, rasa ingin tahu, dan self-efficacy siswa maka semakin baik pula kemampuan penalaran matematika yang dimiliki siswa tersebut.

\section{Uji Hipotesis Kedua}

Hipotesis kedua yaitu ada hubungan antara kemampuan koneksi matematika dengan kemampuan penalaran matematika siswa. Untuk menguji hipotesis tersebut, data dianalisis dengan menggunakan regresi berganda. Hasil analisis tersebut secara lengkap dapat dilihat pada Tabel 6.

Tabel 6 menunjukkan koefisien regresi untuk kemampuan koneksi matematis (X1) adalah 0,422 yang bernilai positif. Berarti kemampuan penalaran matematis akan meningkat apabila kemampuan koneksi matematis ditingkatkan. Semakin tinggi kemampuan koneksi matematis, semakin tinggi pula kemampuan penalaran matematis siswa. Hubungan antara kemampuan koneksi matematis dengan 
kemampuan penalaran matematis siswa juga signifikan $(t=10,421 ; p=0,00)$. Berdasarkan hasil analisis regresi ganda dapat disimpulkan bahwa kemampuan koneksi matematis berhubungan dengan kemampuan penalaran matematis. Kontribusi murni variabel kemampuan koneksi matematis terhadap kemampuan penalaran matematis siswa dengan mengendalikan variabel rasa ingin tahu dan self-efficacy matematika berdasarkan hasil perhitungan koefisien determinasi parsial yaitu 23,27\%.

Tabel 6. Hasil Pengujian Signifikansi Koefisien Regresi

\begin{tabular}{llll}
\hline Model & Koefisien Regresi & Nilai $t$ & $p$ \\
\hline Konstanta & 0,97 & 0,850 & 0,396 \\
$\mathrm{X}_{1}$ & 0,422 & 10,421 & 0,000 \\
$\mathrm{X}_{2}$ & 0,059 & 3,652 & 0,000 \\
$\mathrm{X}_{3}$ & 0,041 & 2,570 & 0,011 \\
\hline
\end{tabular}

\section{Uji Hipotesis Ketiga}

Hipotesis ketiga yaitu ada hubungan yang signifikan antara rasa ingin tahu dengan prestasi kemampuan penalaran matematis siswa SMA. Tabel 6 menunjukkan bahwa koefisien regresi untuk rasa ingin tahu $\left(\mathrm{X}_{2}\right)$ adalah 0,059 yang bernilai positif. Berarti kemampuan penalaran matematis akan meningkat apabila rasa ingin tahu ditingkatkan. Semakin tinggi rasa ingin tahu, semakin tinggi pula kemampuan penalaran matematis siswa. Selain itu, hubungan antara rasa ingin tahu dengan kemampuan penalaran matematis siswa terbukti signifikan $(t=3,652 ; p=0,00)$. Kontribusi murni variabel kemampuan rasa ingin tahu terhadap kemampuan penalaran matematis siswa dengan mengendalikan variabel kemampuan koneksi matematika dan variabel self-efficacy berdasarkan hasil perhitungan koefisien determinasi parsial adalah 3,59\%.

\section{Uji Hipotesis Keempat}

Hipotesis keempat yaitu ada hubungan yang signifikan antara self-efficacy dengan kemampuan penalaran matematika siswa SMA. Tabel 6 menunjukkan bahwa koefisien regresi untuk self-efficacy (X3) adalah 0,041 yang bernilai positif. Berarti kemampuan penalaran matematis akan meningkat apabila self-efficacy ditingkatkan. Semakin tinggi self-efficacy, semakin tinggi pula kemampuan penalaran matematis siswa. Meskipun koefisien regresi hubungan antara self-efficacy dengan kemampuan penalaran matematis siswa kecil, tetapi hubungan tersebut masih signifikan $(t=2,570 ; p=0.01)$. Kontribusi murni variabel self-efficacy terhadap kemampuan penalaran matematis siswa dengan mengendalikan variabel kemampuan koneksi matematis dan variabel rasa ingin tahu berdasarkan hasil perhitungan koefisien determinasi parsial adalah $1,81 \%$.

\section{Pembahasan}

Penelitian ini mengungkapkan hubungan antara kemampuan koneksi matematika, rasa ingin tahu, dan self-efficacy dengan kemampuan penalaran matematika siswa SMA kelas X. Sampel penelitian diambil dari siswa kelas X SMA Negeri se-Kabupaten Brebes. Berdasarkan hasil penelitian yang telah dipaparkan, hasil pengujian hipotesis menunjukkan bahwa terdapat hubungan yang signifikan antara kemampuan koneksi matematis, rasa ingin tahu, dan self-efficacy dengan kemampuan penalaran matematis baik secara bersama-sama maupun secara individual. Hal ini menunjukkan bahwa semua hipotesis yang dikemukakan dalam penelitian ini diterima.

Jika dilihat dari hubungan antara kemampuan koneksi dan penalaran, temuan penelitian ini sesuai dengan temuan penelitian (Badjeber \& Fatimah, 2015). Kemampuan koneksi matematis merupakan kemampuan yang tidak bisa dipisahkan dari matematika. Setiap konsep, prinsip, dan keterampilan dalam matematika dikonsepkan dengan konsep, prinsip, dan keterampilan lainnya. Kemampuan koneksi matematis membantu siswa untuk dapat menilai matematika sebagai sesuatu konsep yang terintegrasi. Sehingga menurut Barmby et al. (2007) salah satu ciri pemahaman siswa mendalam dapat diketahui dari kemampuan koneksi matematisnya.

Kemampuan koneksi matematis penting untuk mengembangkan kemampuan penalaran matematis siswa, begitu pun sebaliknya, kemampuan penalaran penting untuk kemampuan koneksi matematis siswa. Hal ini sesuai dengan pendapat Amir-Mofidi et al. (2012, p. 2921) yaitu kemampuan penalaran membantu siswa untuk menghubungkan pengetahuan saat ini dengan pengetahuan baru tanpa merasa kesulitan. Salah satu indikator dalam kemampuan penalaran matematika adalah generalisasi. Dalam 
generalisasi ini kemampuan koneksi matematis sangat dibutuhkan. Pada proses ini, siswa diminta untuk membuat pola dan hubungan antar pola tersebut (Hashemia et al., 2013). Siswa dengan kemampuan koneksi matematis yang baik akan lebih mudah melakukan proses generalisasi dibandingkan dengan siswa yang memiliki kemampuan koneksi matematis yang rendah. Hal tersebut disebabkan karena kemampuan koneksi matematis adalah kemampuan seseorang dalam melihat, mengenali, membuat dan menerapkan hubungan antar topik matematika, matematika dengan disiplin ilmu lainnya, dan antara matematika dengan kehidupan sehari-hari guna membangun pemahaman konsep matematika siswa.

Hasil yang diperoleh dalam penelitian ini menunjukkan bahwa kemampuan koneksi matematis perlu ditingkatkan atau dikembangkan dalam rangka mengembangkan kemampuan penalaran matematis siswa. Beberapa cara yang dapat dilakukan adalah dengan menerapkan pembelajaran matematika yang mendukung perkembangan kemampuan koneksi matematis dan juga memperbanyak latihan-latihan soal cerita matematika yang melatih kemampuan koneksi matematis siswa. Berdasarkan pada hasil analisis korelasi terlihat adanya perbedaan yang cukup besar sumbangan kemampuan koneksi matematis secara bersama-sama dengan rasa ingin tahu dan self-efficacy terhadap kemampuan penalaran matematis dibandingkan dengan ketika variabel rasa ingin tahu dan self-efficacy dikendalikan. Pada saat rasa ingin tahu dan self-efficacy dikendalikan, besar sumbangan menjadi lebih kecil. Hal tersebut menunjukkan dalam hubungan antara kemampuan koneksi matematika dengan kemampuan penalaran matematika, rasa ingin tahu dan self-efficacy tidak bisa diabaikan.

Kemampuan koneksi yang baik akan membantu siswa memiliki kemampuan penalaran yang baik pula, akan tetapi apabila hal tersebut tidak didukung dengan rasa ingin tahu siswa yang tinggi terhadap materi yang akan dipelajari maka upaya perbaikan kemampuan koneksi matematis siswa dalam upaya mendukung mengembangkan kemampuan penalaran matematis tidak akan efektif. Dalam proses pembelajaran rasa ingin tahu sangat diperlukan oleh siswa dalam membantu membuat hubungan baru antara ide-ide, persepsi, konsep, dan representasi. Seseorang yang memiliki rasa ingin tahu terhadap matematika yang tinggi akan terdorong untuk membuat hubungan antar konsep-konsep matematika. Hal tersebut tentu saja menunjukkan bahwa rasa ingin tahu berpengaruh dalam meningkatkan kemampuan koneksi matematis siswa dalam rangka meningkatkan kemampuan penalaran matematis.

Demikian pula dengan kemampuan koneksi matematis, apabila tidak didukung oleh self-efficacy yang baik terhadap matematika, maka upaya perbaikan kemampuan koneksi matematis siswa dalam meningkatkan kemampuan penalaran matematis siswa tidak efektif. Self-efficacy menyangkut keyakinan siswa akan kemampuan dirinya mampu memahami dan mempelajari matematika dengan baik juga menjadi faktor yang diperlukan oleh siswa. Sebaik apapun kemampuan koneksi matematis yang dimiliki siswa jika siswa tidak memiliki keyakinan akan dirinya bahwa dia mampu menyelesaikan soal terkait kemampuan koneksi matematis, siswa pasti akan ragu dengan hasil pekerjaannya. Akibatnya akan berdampak pula pada kemampuan penalaran matematis siswa.

Adapun rasa ingin tahu adalah keinginan untuk memahami dan mempelajari matematika lebih mendalam guna mendapatkan pengetahuan baru yang ditunjukkan melalui kegiatan eksplorasi dan keaktifan bertanya. Rasa ingin tahu membantu menumbuhkan keinginan siswa dalam mempelajari matematika lebih mendalam dan mengeksplorasi konsep matematika secara luas. Seseorang yang tidak memiliki rasa ingin tahu terhadap matematika cenderung malas dan cepat bosan terhadap materi yang diajarkan, namun sebaliknya seseorang yang memiliki rasa ingin tahu yang tinggi terhadap matematika maka cenderung memiliki semangat dan usaha yang lebih baik dalam mempelajari matematika itu sendiri.

Rasa ingin tahu siswa berperan penting dalam mengembangkan kemampuan penalaran siswa. Rasa ingin tahu yang tinggi dapat membuat siswa tidak mudah menyerah dalam menghadapi soal matematika yang sulit atau belum dipahami. Rasa ingin tahu memiliki pengaruh pada kemampuan penalaran matematis siswa. Salah satu aspek dalam kemampuan penalaran matematis adalah menyelidiki atau mengevaluasi kebenaran dari suatu konjektur. Siswa yang memiliki rasa ingin tahu yang tinggi membuat siswa tidak mudah puas terhadap pengetahuan yang diperoleh, sehingga siswa yang memiliki rasa ingin tahu yang tinggi cenderung menyelidiki pengetahuan yang didapat. Dalam kaitannya dengan kemampuan penalaran matematis, siswa yang memiliki rasa ingin tahu tinggi lebih tertantang untuk menyelidiki konjektur dalam soal atau permasalah penalaran matematis yang diberikan. Seseorang yang memiliki rasa ingin tahu tinggi akan menganggap masalah sebagai tantangan yang harus dipecahkan dari pada sesuatu yang tidak bisa diatasi, sehingga meningkatkan kemampuan mereka untuk menemukan berbagai cara dalam menghadapi kesulitan (Denneson et al., 2017, p. 127). Hasil penelitian telah 
menunjukkan bahwa rasa ingin tahu adalah salah satu bentuk motivasi intrinsik yang merupakan kunci dalam mengembangkan pembelajaran yang aktif dan melakukan kegiatan eksplorasi secara mandiri (Tang, 2017). Seseorang yang memiliki rasa ingin tahu akan gemar melakukan eksplorasi secara mandiri, dimana hal ini tentu akan berdampak positif pada kemampuan penalaran siswa.

Penelitian ini juga mengangkat hubungan antara rasa ingin tahu dengan kemampuan penalaran matematika siswa SMA kelas X di kabupaten Brebes. Temuan penelitian ini sejalan dengan temuan penelitian Wicaksana et al. (2017) yang mengungkapkan bahwa aspek karakter rasa ingin tahu memiliki pengaruh positif terhadap kemampuan literasi matematika. Selain itu terdapat hasil penelitian pendukung lainnya yaitu penelitian yang dilakukan oleh Lawson et al. (2007), dimana salah satu hasil dari penelitian ini menunjukkan bahwa self-efficacy dan kemampuan penalaran memiliki hubungan yang positif. Pada penelitian tersebut dilaporkan bahwa kemampuan penalaran merupakan prediktor yang kuat bagi self-efficacy, akan tetapi self-efficacy bukanlah prediktor yang kuat bagi kemampuan penalaran. Dari penelitian ini didapatkan bahwa kemampuan penalaran merupakan faktor utama yang mempengaruhi self-efficacy dan prestasi belajar yang dimiliki.

Faktor self-efficacy juga tidak dapat diabaikan dalam hubungan antara rasa ingin tahu dengan kemampuan penalaran matematis. Self-efficacy terkait dengan keyakinan tentang kemampuan diri. Seorang siswa yang memiliki rasa ingin tahu cenderung tertantang dengan soal atau permasalahan matematika yang sulit. Perasaan tertantang itu akhirnya melahirkan aktivitas eksplorasi guna mendapatkan jawaban yang benar atas soal yang sulit. Seseorang yang memiliki rasa ingin tahu yang baik namun tidak memiliki self-efficacy yang baik, meskipun dia memiliki keinginan untuk bereksplorasi biasanya cenderung mudah menyerah dan sulit untuk memulai sesuatu karena beranggapan dia tidak memiliki kemampuan untuk menyelesaikan permasalahan matematika tersebut, meskipun dia ingin mengetahui jawaban yang benar. Oleh karena itu, rasa ingin tahu yang baik dan didukung oleh adanya kemampuan koneksi matematis dan self-efficacy self-efficacy yang baik akan mendukung kemampuan penalaran matematis lebih baik.

Adapun self-efficacy memiliki peranan penting karena self-efficacy memiliki dampak yang sangat positif bagi siswa yang memilikinya. Self-efficacy dapat mempengaruhi seseorang dalam berpikir, merasakan, memotivasi diri sendiri dan bertindak (Bandura, 1995). Siswa yang memiliki self-efficacy yang baik akan memiliki keyakinan akan kemampuan dirinya dan memotivasi dirinya untuk mencapai tujuan yang diharapkannya. Dalam hal ini siswa yang memiliki self-efficacy yang baik terhadap matematika, maka ia akan memiliki keyakinan bahwa dia akan mampu memahami matematika dengan baik dan memotivasi dirinya untuk mendapatkan hasil belajar yang baik. Hal ini didukung oleh pernyataan Lunenberg (Utami \& Wutsqa, 2017, p. 167) yang menyatakan bahwa self-efficacy memiliki pengaruh yang kuat terhadap pembelajaran, motivasi, dan kinerja seseorang.

\section{SIMPULAN}

Berdasarkan hasil penelitian dan pembahasan dapat disimpulkan bahwa terdapat hubungan antara kemampuan koneksi matematika, rasa ingin tahu, dan self-efficacy secara simultan dengan kemampuan penalaran matematika siswa SMA kelas X di Kabupaten Brebes $(R=0,684, p=0,00)$. Kemampuan koneksi matematika, rasa ingin tahu, dan self-efficacy secara bersama-sama memberikan pengaruh sebesar 46,3\% kepada kemampuan penalaran matematika siswa. Terdapat hubungan positif yang signifikan antara kemampuan koneksi matematika dengan kemampuan penalaran matematika siswa SMA kelas X di Kabupaten Brebes $(t=10,241, p=0,00)$ dengan kontribusi murni sebesar 23,27\%. Terdapat hubungan positif yang signifikan antara rasa ingin tahu dengan kemampuan penalaran matematis siswa SMA kelas X di Kabupaten Brebes $(t=3,652, p=0,00)$ dengan kontribusi murni $3,59 \%$. Terdapat hubungan positif yang signifikan antara self-efficacy dengan kemampuan penalaran matematis siswa SMA kelas X di Kabupaten Brebes $(t=2,570, p=0,00)$ dengan kontribusi murni sebesar 1,181 .

Kemampuan koneksi matematika memberikan kontribusi terbesar pada kemampuan penalaran matematika siswa dibandingkan dengan rasa ingin tahu dan self-efficacy. Oleh karena itu, hendaknya guru menekankan pada peningkatan kemampuan koneksi matematika dengan cara memberikan latihan soal cerita yang bermuatan aspek-aspek kemampuan koneksi matematika. Misalnya, untuk aspek koneksi matematika dengan mata pelajaran lainnya, guru dapat memberikan contoh soal cerita matematika yang di dalamnya terkandung muatan mata pelajaran lain seperti fisika, biologi dan lain 
sebagainya. Besar sumbangan ketiga variabel bebas terhadap variabel terikat dalam penelitian ini hanya 48\%. Hal ini menandakan masih terdapat beberapa variabel lain yang mempengaruhi kemampuan penalaran matematis siswa. Hal tersebut memungkinkan bagi peneliti lain untuk menambahkan variabel lainnya yang berhubungan dengan kemampuan penalaran matematis.

\section{DAFTAR PUSTAKA}

Amir-Mofidi, S., Amiripour, P., \& Bijan-Zadeh, M. H. (2012). Instruction of mathematical concepts through analogical reasoning skills. Indian Journal of Science and Technology, 5(6), 2916-2922.

Azwar, S. (2004). Metode penelitian. Pustaka Pelajar.

Badjeber, R., \& Fatimah, S. (2015). Peningkatan kemampuan koneksi matematis siswa SMP melalui pembelajaran inkuiri model Alberta. Jurnal Pengajaran Matematika Dan Ilmu Pengetahuan Alam, 20(1), 18. https://doi.org/10.18269/jpmipa.v20i1.557

Ball, D. L., Lewis, J., \& Thames, M. H. (2008). Chapter 1: Making mathematics work in school. Journal for Research in Mathematics Education. Monograph, 14, 13-201.

Bandura, A. (1995). Self-efficacy in changing societies. Cambridge University Press.

Barmby, P., Harries, T., Higgins, S., \& Suggate, J. (2007). How can we assess mathematical understanding. Proceedings of the 31 st Conference of the International Group for the Psychology of Mathematics Education, 2, 41-48.

Bhowmick, S., Young, J. A., Clark, P. W., \& Bhowmick, N. (2017). Marketing students' mathematics performance: The mediating role of math anxiety on math self-concept and math self-efficacy. Journal of Higher Education Theory and Practice, 17(9). https://doi.org/10.33423/jhetp.v17i9.1426

Bieda, K. N., Ji, X., Drwencke, J., \& Picard, A. (2014). Reasoning-and-proving opportunities in elementary mathematics textbooks. International Journal of Educational Research, 64, 71-80. https://doi.org/10.1016/j.ijer.2013.06.005

Brodie, K. (2010). Teaching mathematical reasoning in secondary school classrooms (K. Brodie (ed.)). Springer US. https://doi.org/10.1007/978-0-387-09742-8

Denneson, L. M., Smolenski, D. J., Bush, N. E., \& Dobscha, S. K. (2017). Curiosity improves coping efficacy and reduces suicidal ideation severity among military veterans at risk for suicide. Psychiatry Research, 249, 125-131. https://doi.org/10.1016/j.psychres.2017.01.018

García-García, J., \& Dolores-Flores, C. (2018). Intra-mathematical connections made by high school students in performing Calculus tasks. International Journal of Mathematical Education in Science and Technology, 49(2), 227-252. https://doi.org/10.1080/0020739X.2017.1355994

Goos, M., Stillman, G., \& Vale, C. (2007). Teaching secondary school mathematics: Research and practice for the 21 st century. Allen \& Unwin.

Hashemia, N., Abua, M. S., Kashefia, H., \& Rahimib, K. (2013). Generalization in the learning of mathematics. Second International Seminar on Quality and Affordable Education (ISQAE). https://educ.utm.my/wp-content/uploads/2013/11/291.pdf

Lawson, A. E., Banks, D. L., \& Logvin, M. (2007). Self-efficacy, reasoning ability, and achievement in college biology. Journal of Research in Science Teaching, 44(5), 706-724. https://doi.org/10.1002/tea.20172

Litman, J. A., \& Spielberger, C. D. (2003). Measuring epistemic curiosity and its diversive and specific components. Journal of Personality Assessment, 80(1), 75-86. https://doi.org/10.1207/S15327752JPA8001_16

McCoach, D. B., Gable, R. K., \& Madura, J. P. (2013). Instrument development in the affective domain. Springer New York. https://doi.org/10.1007/978-1-4614-7135-6

Peraturan Menteri Pendidikan dan Kebudayaan Republik Indonesia Nomor 21 Tahun 2016 tentang Standar Isi Pendidikan Dasar dan Menengah, Pub. L. No. 64, Peraturan Menteri Pendidikan dan Kebudayaan Republik Indonesia (2016).

Ministry of Education. (2007). Science syllabus-lower secondary. Curriculum Planning \& Development 
Design.

National Council of Teachers of Mathematics. (2000). Principles and standards for school mathematics. National Council of Teachers of Mathematics.

National Council of Teachers of Mathematics. (2009). Focus in high school mathematics: Reasoning and sense making. National Council of Teacher of Mathematics. http://www.nctm.org

Ontario Ministry of Education. (2005). The Ontario curriculum, grades 1 to 8: Mathematics. Queen's Printer for Ontario.

Organisation for Economic Co-operation and Development. (2013). PISA 2012 assessment and analytical framework: Mathematics, reading, science, problem solving and financial literacy. OECD. https://doi.org/10.1787/9789264190511-en

Organisation for Economic Co-Operation and Development. (2004). Learning for tomorrow's world. OECD. https://doi.org/10.1787/9789264006416-en

Organisation for Economic Co-Operation and Development. (2009). Factbook 2010: Economic, environmental and social statistics. OECD. https://doi.org/10.1787/factbook-2009-graph126-en

Organisation for Economic Co-Operation and Development. (2010). PISA 2009 results: What students know and can do: Student performance in reading, mathematics and science (1st ed.). OECD Publishing. https://doi.org/10.1787/9789264091450-en

Organisation for Economic Co-Operation and Development. (2014). PISA 2012 results: What students know and can do (Volume I, Revised edition, February 2014). OECD. https://doi.org/10.1787/9789264208780-en

Organisation for Economic Co-Operation and Development. (2016). PISA 2015 results (Volume I): Excellence and equity in education: Vol. I. OECD. https://doi.org/10.1787/9789264266490-en

Ormord, J. E. (2009). Psikologi pendidikan membantu siswa tumbuh dan berkembang (A. Kumara \& R. Rahmat (trans.)). Erlangga.

Renner, B. (2006). Curiosity about people: The development of a social curiosity measure in adults. $\begin{array}{llll}\text { Journal of Personality } & \text { Assessment, }\end{array}$ https://doi.org/10.1207/s15327752jpa8703_11

Reys, R. E., Lindquist, M. M., Lambdin, D. V., \& Smith, N. L. (2014). Helping children learn mathematics. Wiley.

Schunk, D. H. (2012). Teori-teori pembelajaran: perspektif pendidikan (E. Hamdiah \& R. Fajar (trans.)). Pustaka Pelajar.

Sengul, S. (2011). Effects of concept cartoons on mathematics self-efficacy of 7th grade students. Educational Sciences: Theory and Practice, 11(4), 2305-2313.

Sidenvall, J., Lithner, J., \& Jäder, J. (2015). Students' reasoning in mathematics textbook task-solving. International Journal of Mathematical Education in Science and Technology, 46(4), 533-552. https://doi.org/10.1080/0020739X.2014.992986

Tang, Y.-Y. (2017). Curiosity and creativity motivate self-learning. In Brain-Based Learning and Education (pp. 19-23). Elsevier. https://doi.org/10.1016/B978-0-12-810508-5.00004-3

Utami, R. W., \& Wutsqa, D. U. (2017). Analisis kemampuan pemecahan masalah matematika dan selfefficacy siswa SMP negeri di Kabupaten Ciamis. Jurnal Riset Pendidikan Matematika, 4(2), 166. https://doi.org/10.21831/jrpm.v4i2.14897

Wicaksana, Y., Wardono, W., \& Ridlo, S. (2017). Analisis kemampuan literasi matematika dan karakter rasa ingin tahu siswa pada pembelajaran berbasis proyek berbantuan schoology. Unnes Journal of Mathematics Education Research, 6(2), 167-174. https://journal.unnes.ac.id/sju/index.php/ujmer/article/view/20475

Witt, M., \& Hansen, A. (2014). Primary mathematics for trainee teachers. SAGE Publications, Inc. https://doi.org/10.4135/9781473909595 